\title{
APPLICATION OF IMAGE PROCESSING TO THE RESEARCH OF CONTACT BEHAVIOR BETWEEN FABRIC SURFACE AND FLAT HARD SURFACE
}

\author{
By Yoshio Shimizu ${ }^{* 1}$, Hiroko Shimizu ${ }^{* 2}$ and Atsuo Konda ${ }^{* 1}$ \\ *1 (Faculty of Textile Science and Technology, Shinshu \\ University, Tokida, Ueda, Japan) \\ *2 (Faculty of Education, Utsunomiya University, \\ Mine-machi, Utsunomiya, Japan)
}

\begin{abstract}
In order to clarify the mechanism of the contact behavior of integrated filament or staple such as knitted fabric and woven fabric, we have developed a system to measure the condition of the contact caused by pressure between fabric and solid hard flat surface. This system is composed of three parts: (1) to apply pressure to a sample, (2) to detect the contact spots and (3) to analyze the detected data.

By using this system we clarified the contact behavior of a polyester taffeta which consists of very crimped warp and of relatively straight weft. As a result we discovered that the mechanism of the contact behavior can be divided into following four regions:

(1) the contact region in which the contact behavior is elastic,

(2) the region in which the contact spot is deformed into slenderness within the warp filament,

(3) the region in which the weft filament comes to contact and

(4) the region in which the contact spots begin to harden by mutual interaction.

As mentioned above, we discovered that this system is of great use in order to analyze the contact behavior of the material with the complicatedly structured surface.
\end{abstract}

\section{INTRODUCTION}

Generally a solid surface has a complicated morphology. And this morphology varies when touching other solid materials. When a solid material is used, it usually contacts with other materials. Many phenomena such as friction, wear, generation of heat, electro static charge, and thermal conduction occur through the contact between solid materials. These phenomena are influenced by the condition of contact surfaces. Not only in the field of physics and engineering, the condition of the contact between a fabric and the surface of human body plays a crucial role in skin feeling that is caused by putting on clothing.

Although the research of the contact can be applied in many fields as mentioned above, few papers on advanced research in this field have apparently been published up to date because of difficulties in measuring the actual contact area. Several methods for measuring the contact area have been applied. For example, they are the electric resistance method ${ }^{1) 2}$, the carbon transferring method ${ }^{3) 4)}$ and the pressure sensitive film method $^{5)}$ and so ${ }^{6}{ }^{6) 7}$ ). By these methods, however, each contact spot could not be observed directly.

Then we have developed an optical method ${ }^{83}$, by which the contact spots could be observed directly. And then we have further developed a precise and direct method using an image processing. The optical apparatus was designed for measuring the contact image between the complicated surface such as fabrics and the flat hard surface. Furthermore the image processing method has been arranged to analyze the contact behavior.

This paper attempts to investigate the pressure dependence of the contact behavior of the fabric 
which is applied under extensive pressure range.

\section{EXPERIMENTAL}

\subsection{The Image Processing System}

The apparatus which was designed for the measurement of the actual contact spot consists of a prism, a slit, a light source, a weight, an anvil, a microscope, a stage, a TV camera and a microcomputer system for the image processing (Fig. 1). The incident beam from the light source passes through the prism and reflects internally at the boundary surface, and then enters the microscope. The microscope is connected to the TV camera so that the contact image can be obtained automatically by the computer system. If the specimen contacts with the surface of the prism, the incident beam does not reflect at the plane on which the specimen is on. Thus the contact spot shows a black image for lack of the light.

Since the focus of a light microscope is not deep enough and the boundary surface of the prism is tilted against the microscope, the image of the contact spots obtained by the apparatus is almost out of focus except for the narrow range (Fig. 2.a). Some devices are needed to get the sharp image of the whole contact spots. The microcomputer system is provided with a step motor and its controller which is possible to shift the microscope within the small range from 0 to $1 \mathrm{~mm}$. By shifting the microscope, the image of the contact spots which is in focus moves on the image plane of the $\mathrm{TV}$ camera. Only the sharp image information on the frame memory is spontaneously extracted and stored in the image memory, while the step motor being controlled. The Fig. 2.b shows the sharp image of the whole contact spots which was

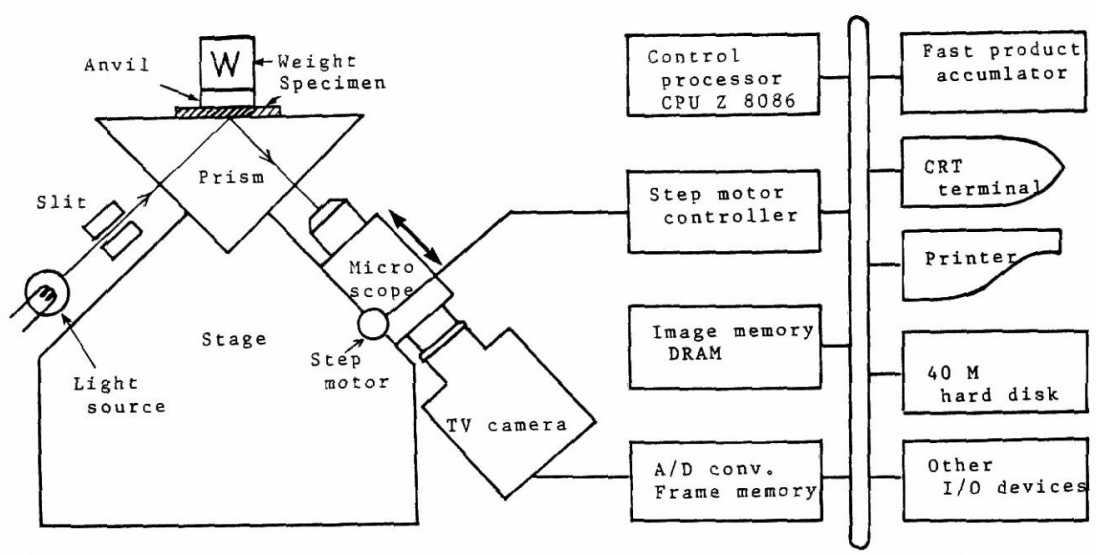

Fig. 1 The image processing system for the measurement of the contact behavior.

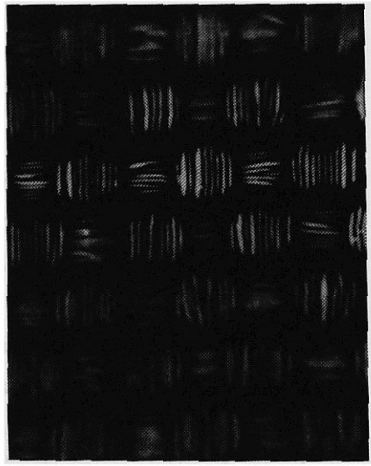

(a)

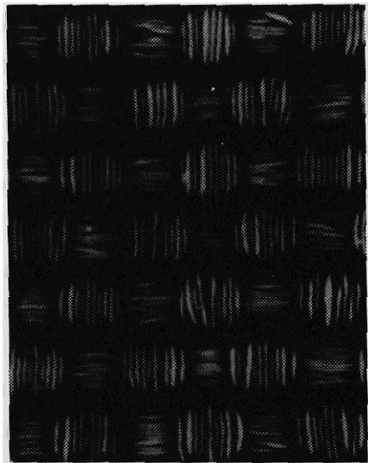

(b) $200, \mu \mathrm{m}$

Fig. 2 The example of actual contact images for polyester taffeta. (a) partially focused image. (b) wholly focused image. 
obtained by the method described above. These data are stored in the hard disk unit and treated by the image processing. The main functions included in this image processing are as follows:

a) detecting the shape of the contact spots,

b) labeling the contact spots and

c) calculating the shape factors of such as area, slenderness, direction, and so on.

Fig. 3 shows the schematic diagram of the slenderness.

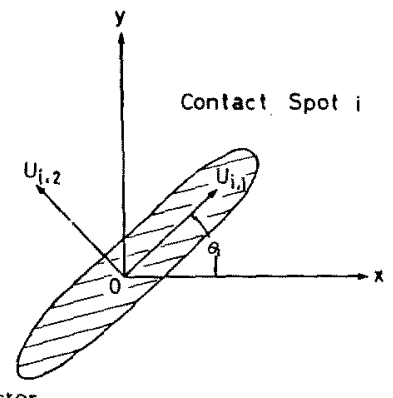

* Unit Vector

$U_{i, 1}$ : unit vector of principal direction $\left(\theta_{i}\right)$ of a contact spot $i$

$U_{i, 2}$ : unit vector which is perpendicular to $U_{i, 1}$

* Moment of Inertia

$I_{i, 1}=\iint\left(\boldsymbol{r}^{2}-\left(\boldsymbol{r} \cdot \boldsymbol{U}_{i, 1}\right)^{2}\right) d x d y$

$I_{i, 2}=\iint\left(\boldsymbol{r}^{2}-\left(\boldsymbol{r} \cdot \boldsymbol{U}_{i, 2}\right)^{2}\right) d x d y$

* Principal Radius of Gyration

$R_{i, 1}=\sqrt{I_{i, 1} / a_{i}}, R_{i, 2}=\sqrt{I_{i, 2} / a_{i}}$

* Slenderness of a contact spor $i$

$s_{i}=R_{i, 1} / R_{i, 2}$

Fig. 3 Schematic diagram of slenderness.

\section{Nomenclature}

$N$ : total number of contact spots per $6 \times 6$ intersecting points

$a_{f} \quad$ the area of contact spot $i\left(\mu \mathrm{m}^{2}\right)$

$A$ : the total contact area of contact spots per $6 \times 6$ intersecting points $\left(\mu \mathrm{m}^{2}\right)=\sum_{i=1}^{N} a_{i}$

$A_{\mathrm{m}}$ : the mean area of contact $\operatorname{spots}\left(\mu \mathrm{m}^{2}\right)=A / N$

$W$ : applied load $(\mathrm{N})$

$P$ : nominal applied pressure $\left(\mathrm{N} / \mathrm{m}^{2}\right)$

$P_{\mathrm{m}} \quad$ mean actual pressure $\left(\mathrm{N} / \mathrm{m}^{2}\right)=P / N$

$s_{i}$ : the value of slenderness of contact spot $i$

$S_{\mathrm{m}}$ the mean value of slenderness of contact spots

C.N.A: the contribution rate of the area of new contact spots to the amount of total area increase $(\%)$

$=($ the area of new contact spots $) / / A_{P_{i+1}}$ $\left.-A_{P_{i}}\right)$

\subsection{The Sample and Loading Arrangement}

Polyester taffeta was used as a sample. The sample has a weight of $73.6 \mathrm{~g} / \mathrm{m}^{2}$ and a thickness of $0.11 \mathrm{~mm}$. The density is 57.0 ends/cm and 38.7 picks $/ \mathrm{cm}$. Counts of warp and weft yarn are 61.4 and $95.1 \mathrm{D}$, respectively. SEM photographs of the sample are shown in Fig. 4. It is shown that the warp yarn is more crimped than the weft yarn and the warp yarn runs on the surface of the fabric.

12 steps of nominal loads were applied to the fabric through the cylindrical anvil whose surface is very flat and whose sectional area is $10 \mathrm{~mm}^{2}$ Nominal applied pressure $\left(P_{i}\right)$ are as follows: $P_{1}=4.21 \times 10^{2}, P_{2}=2.38 \times 10^{3}, P_{3}=4.34 \times 10^{3}, P_{4}=$ $1.41 \times 10^{4}, P_{5}=3.37 \times 10^{4}, P_{6}=9.80 \times 10^{4}, P_{7}=2.94$ $\times 10^{5}, P_{8}=1.18 \times 10^{6}, P_{9}=2.94 \times 10^{6}, P_{10}=8.57 \times 10^{6}$, $P_{11}=1.64 \times 10^{7}$ and $P_{12}=2.99 \times 10^{7} \mathrm{~N} / \mathrm{m}^{2} \quad$ The contact images of the fabric were obtained at each nominal pressure and analyzed by the image processing.

\section{RESULTS AND DISCUSSION}

\section{The Image of Contact Spots}

Fig. 5 shows some examples of the final images of the contact spots which were obtained by the image processing. In the case of the smaller pressure $\left(P_{4}\right)$ the contact spots are elliptical shapes which are close to round (Fig. 5.a). When the greater pressure $\left(P_{B}\right)$ is applied, the contact spots of the warp yarns become large and slender and those of the weft yarns appear (Fig. 5.b). At greatest pressure $\left(P_{12}\right)$ of this examination, both warp and weft contact spots become larger and slenderer. The shapes of warp contact spots are larger and longer than those of the wefts as shown in Fig. 5.c.

\section{Total Contact Area $(\boldsymbol{A})$}

As the pressure increases, the total contact area $(A)$ increases gradually. Fig. 6 shows the characteristic curves of a pressure-contact area on a $\log$ - $\log$ basis. It is regarded that the curve $A$ consists of four regions (region I: $P_{1} \leq P<P_{4}$, region II: $P_{4} \leq P<P_{8}$, region 111: $P_{8} \leq P<P_{11}$, region IV: $\left.P_{11} \leq P \leq P_{12}\right)$. In each region the curve $A$ is a straight line. The slopes of each straight line are $0.49,0.73,0.84$ and 0.57 , respectively. 


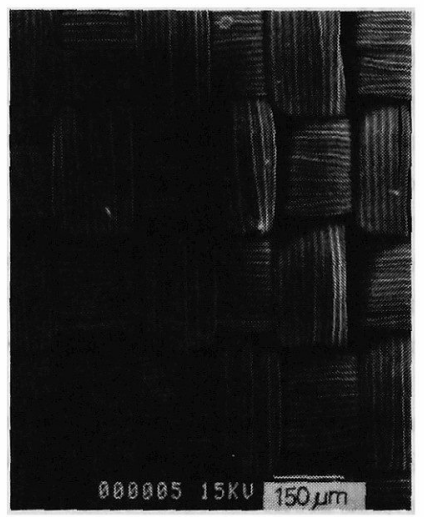

(a)

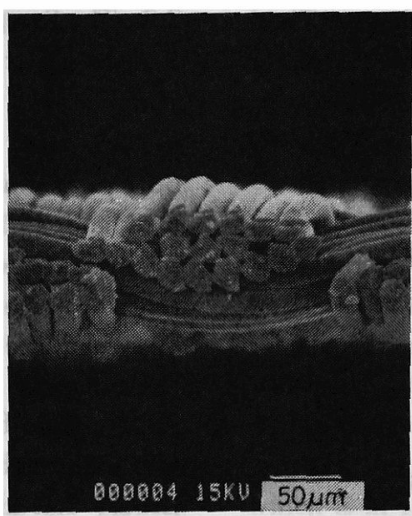

(b)

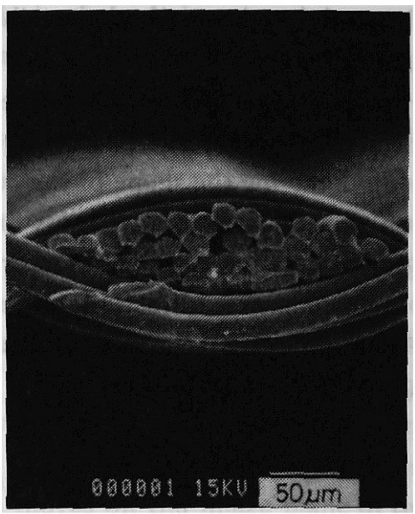

(c)

Fig. 4 SEM photographs of the polyester taffeta which is used in this experiment.

(a) plane (b) cross section of warp yarn (c) cross section of weft yarn

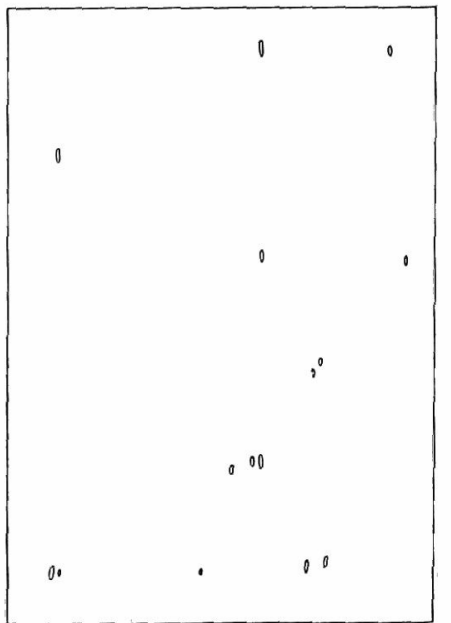

(a)

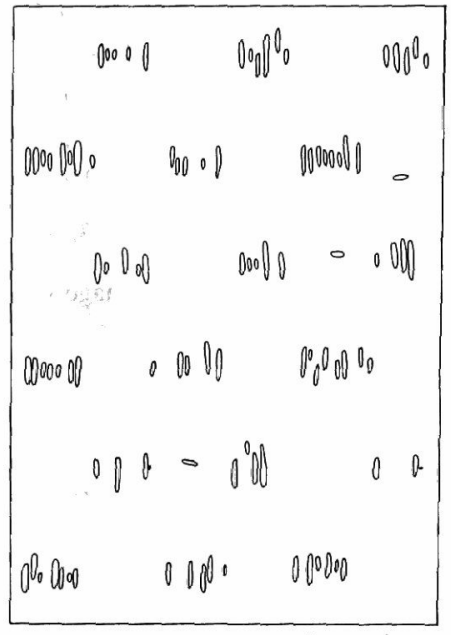

(b) F150um-
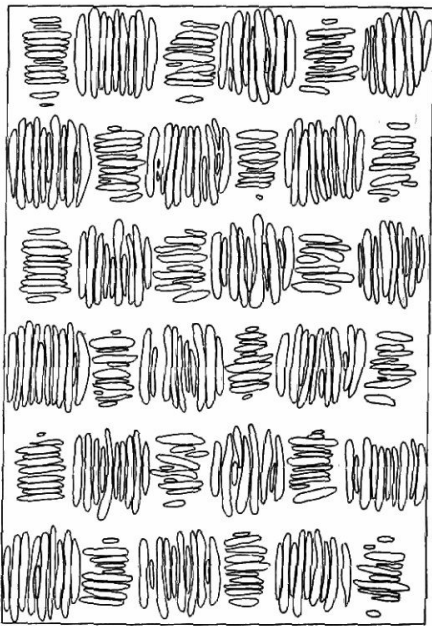

(c) F150/m-

Fig. 5 Graphical representation of actual contact spots obtained by the image processing.

(a) at applied pressure $P_{4}\left(1.41 \times 10^{4} \mathrm{~N} / \mathrm{m}^{2}\right)$

(b) at applied pressure $P_{8}\left(1.18 \times 10^{6} \mathrm{~N} / \mathrm{m}^{2}\right)$

(c) at applied pressure $P_{12}\left(2.99 \times 10^{7} \mathrm{~N} / \mathrm{m}^{2}\right)$

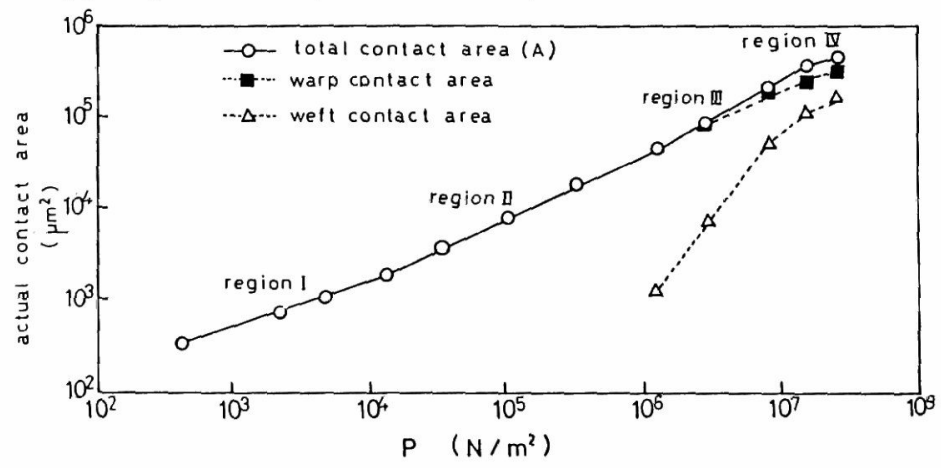

Fig, 6 The characteristic curves of a pressure-contact area. 
The value of $A$ is the sum of the contact area of the warp yarns and of the weft yarns. The values of $A$ in region I and II are only due to the contact area of the warp yarns. The contact area of the weft yarns can be observed in region III and IV. The contact area of warp yarns is larger than that of weft yarns.

The ratios of the total actual contact area to the nominal contact area under the pressures from $P_{1}$ to $P_{12}$ are $0.02,0.05,0.06,0.12,0.24,0.52$, $1.14,2.97,5.75,15.2,25.7$, and $36.2 \%$, respectively. At greatest pressure of this examination it is $36.2 \%$, while at smallest pressure it is only $0.02 \%$.

\section{Mean Area of Contact Spots $\left(A_{\mathrm{m}}\right)$}

Fig. 7 shows that the mean contact area depends on the pressure. The behavior of $A_{\mathrm{m}}$ is similar to the total contact area $A$. That is, the value of $A_{\mathrm{m}}$ increases with a pressure increase and the curve consists of four regions. The mean area of contact spots of the warp yarns is larger than that of the weft yarns.

\section{Distribution of Contact Area of a Spot}

Fig. 8 shows the histogram of the contact area at various applied pressure. At smaller pressure the smaller contact spots exist. As the pressure increases a lots of greater contact spots appear.

Degree of Slenderness $\left(S_{\mathrm{m}}\right)$

The relation between the degree of mean slenderness and the pressure is shown in Fig. 9. Under smaller pressure corresponding to region I, $S_{\mathrm{m}}$ remains constant or even decreases slightly.

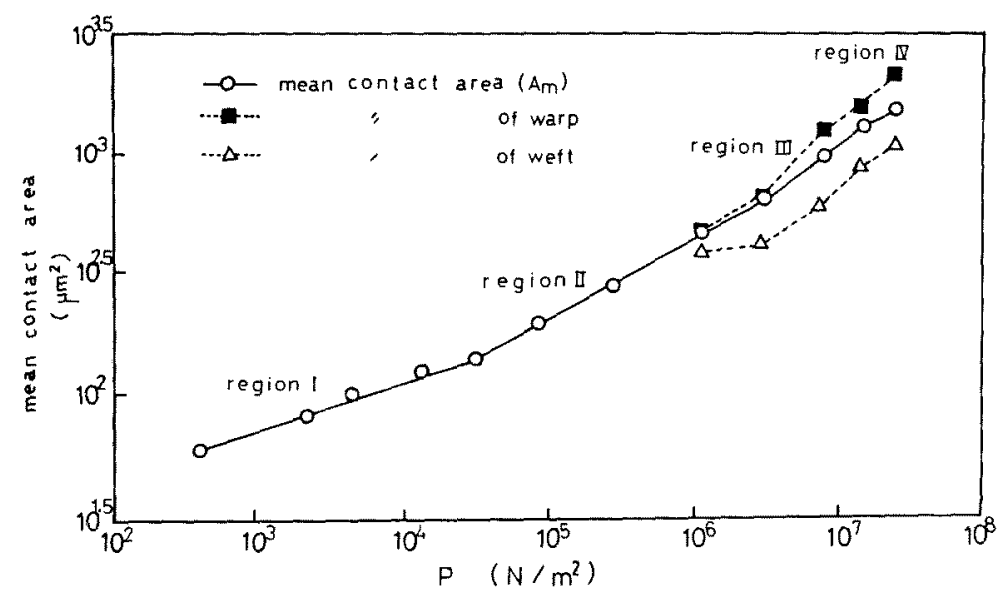

Fig. 7 The characteristic curves of the mean contact area.

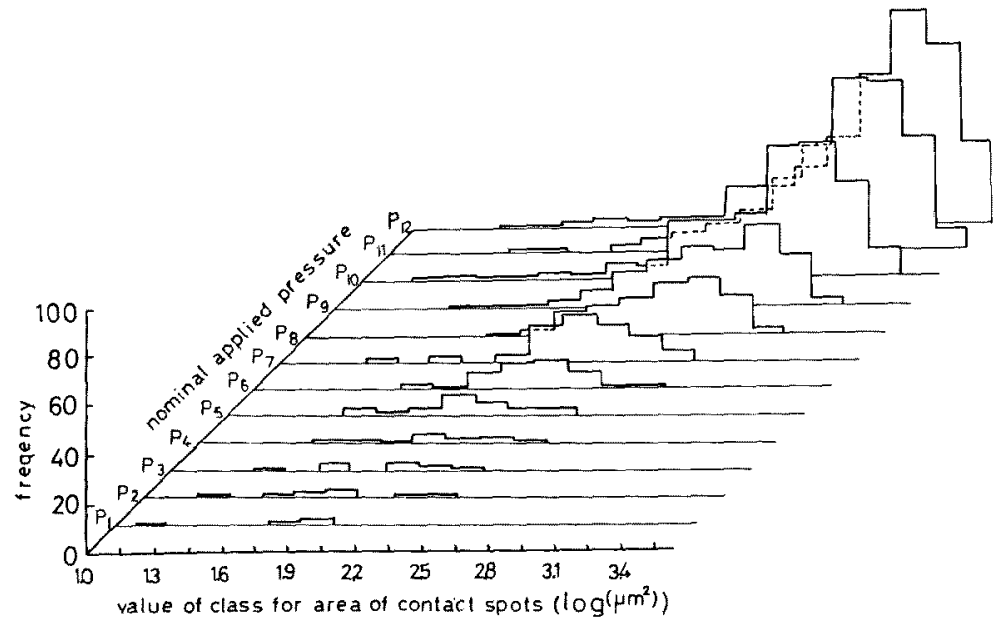

Fig. 8 The histogram of contact area at various applied pressure. 


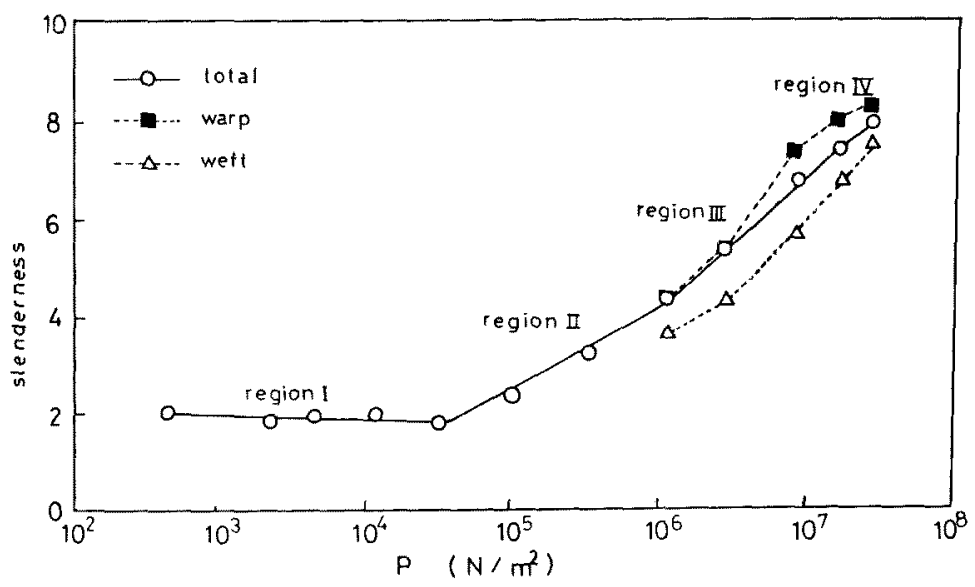

Fig. 9 The characteristic curves of slenderness.

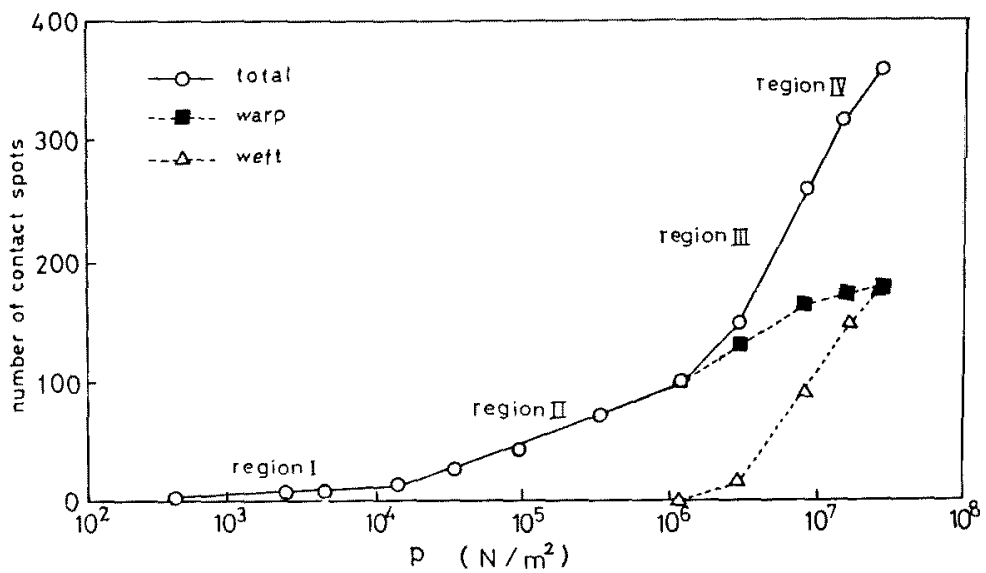

Fig. 10 The contact number at various applied pressure.

Under greater pressure (region II, III, IV), $S_{m}$ increases with the pressure increase. From region Il, $S_{m}$ increases rapidly. This tendency is remarkable in the slenderness of the warp yarn.

The Total Contact Number $(N)$

The total number of the contact spots $(N)$ increases with additional pressure (Fig. 10). Corresponding to the four regions (I, II, III, IV) described above, the curve of $N$ is divided into four regions.

$N$ is the total number of the contact spots of the warp and weft yarns. At the applied pressure $P_{8}$, only three contact points of the weft yarns appear for the first time and then the number of the weft contact spots increases rapidly with the pressure increase.

\section{The Contribution Rate of New Contact Area (C.N.A)}

Total area increase is obtained as the sum of the growth of already contacted spots and of the area of new contact spots. Fig. 11 shows the contribution rate of the new contact area (C.N.A) to the amount of total area increase. Till the applied pressure reaches $P_{5}$ (region I), C.N.A increases. It decreases in region II and increases again in region III. Finally in the region IV, it decreases rapidly.

Mean Actual Pressure $\left(P_{\mathrm{m}}\right)$

The value of mean actual pressure $\left(P_{\mathrm{m}}\right)$ is calculated as $P / A . P_{\mathrm{m}}$ was plotted in Fig. 11 and its curve is regarded as the link of four straight lines whose slopes are $0.52,0.29,0.13$ and 0.43 . Each region of these straight lines shows a very 


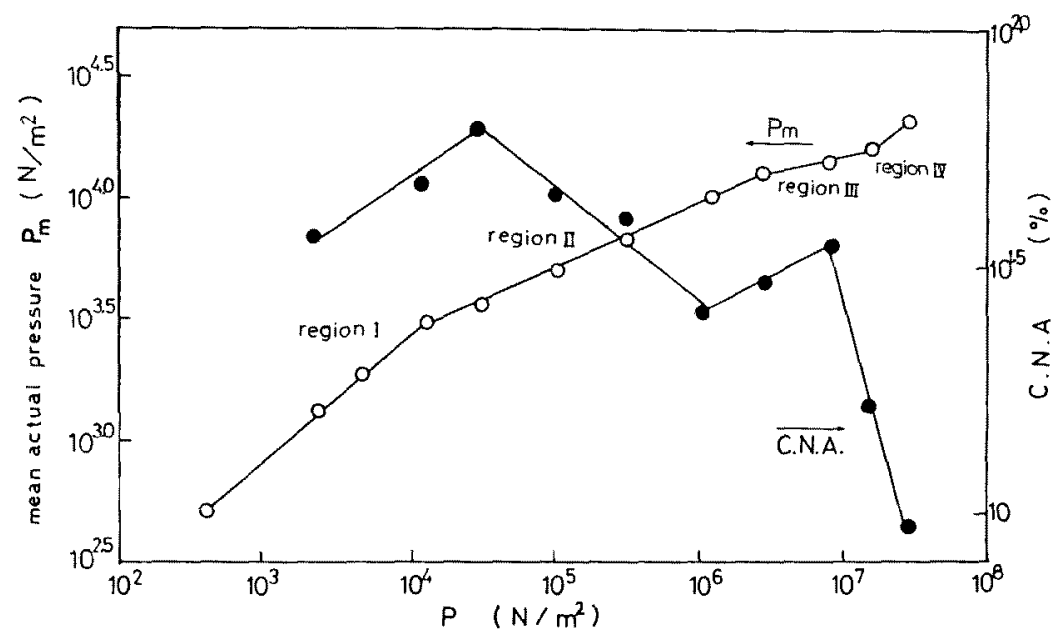

Fig. 11 The plots of the contribution rate of new contact area (C.N.A) and of the mean actual pressure $\left(P_{\mathrm{m}}\right)$ at various applied pressure.

similar feature to each region of the contact area.

\section{Discussion}

The smallest micro-spot that is observed in our study is $2.2 \mu \mathrm{m}$ in width. Even if smaller contact spots than that exist, those spots can not be detected with this optical method. Then we treated the contact area obtained by this system as the actual contact area.

From above results, we concluded that the mechanism of the contact is divided the following four regions.

Region I $\left(P \leq P_{4} \sim P_{5}\right)$ : As the pressure is applied and a specimen is pressed between flat hard surfaces, the protruded parts of the fabric surface deform until the actual contact area becomes sufficient to support the applied pressure. These protruded parts in the warp yarns are shown in Fig. 4. The total contact number $(N)$ increases very slowly (Fig. 10) and the contribution rate of the new contact area (C.N.A) increases (Fig. 11).

Although the mean contact area $\left(A_{\mathrm{m}}\right)$ increases (Fig. 7), the mean value of slenderness $\left(S_{\mathrm{m}}\right)$ decreases slightly or remains constant (Fig. 9). In this stage the behavior of the contact area is reversible. The slope of region I for the $\log P-$ $\log A$ plots (Fig. 6) is 0.49 . The Hertzian theory $\left.{ }^{9}\right)$ of elastic deformation shows that $A$ is in proportion to $P^{2 / 3}$ and the plastic deformation theory ${ }^{10}$ ) shows that $A$ is in proportion to $P$. The slopes calculated from these theories are 0.67 and 1.0, respectively. Our result in region I does not agree with them. Then we assume that region I is based on a certain kind of elastic deformation which is related with the elastic property of the filament or the structure of the fabric.

Region II $\left(P_{4} \sim P_{5}<P \leq P_{8} \sim P_{9}\right):$ The observation shows that at this stage, the increase of $S_{\mathrm{m}}$ occurs (Fig. 9) and other values $\left(A, A_{\mathrm{m}}, N, P_{\mathrm{m}}\right)$ also increase (Fig. 6, 7, 10, 11). It is interesting to note that C.N.A decreases (Fig. 11). This suggests that the increase of the contact area is largely due to the increase of slenderness $\left(S_{\mathrm{m}}\right)$. Region II is the stage where the increase of the total contact area mainly depends on the deformation for slenderness of filaments in the warp yarns.

Region III $\left(P_{8} \sim P_{9}<P \leq P_{10} \sim P_{11}\right):$ In this stage, the weft yarn starts to contact with the flat hard surface and values of $A, A_{\mathrm{m}}, S_{\mathrm{m}}, ' N$, and C.N.A increase rapidly. The slope of $P_{\mathrm{m}}$ in this region shows the least value of 0.13 compared with those of other regions. And the slope of $A$ in region III $(0.84)$ comes close to the value of 1.0 which is expected from the plastic deformation theory. These results imply that the increase in the contact area occurs by the plastic yielding of the contacting filament and by the emergence of the contact spots of the weft yarns at this stage.

Region IV $\left(P_{10}-P_{11}<P \leq P_{12}\right)$ : At the final stage of this examination, the increase rates of $A$, 
$A_{\mathrm{m}}, S_{\mathrm{m}}$ and $N$ go down and the C.N.A decreases extremely. The rapid rise of $P_{\mathrm{m}}$ begins again. This is because the spaces between filaments become narrow and filaments get packed closely (Fig. 5.c). This rise can be explained by the hypothesis that the contact spots harden through mutual interaction between filaments contacting with each other.

\section{CONCLUSION}

We have developed the system for measuring the contact behavior between the fabric surface and the flat hard surface. This measuring system was applied to investigate the pressure dependence of the contact behavior between the polyester taffeta and the flat hard surface. Following results were obtained.

The mechanism of the contact behavior can be divided into following four regions:

(1) the contact region in which the contact behavior is elastic,

(2) the region in which the contact spot is deformed into slenderness within the warp filament,

(3) the region in which the weft filament comes to contact and
(4) the region in which the contact spots begin to harden by mutual interaction.

From the results described above, the system developed by us appears to be useful for the analysis of the contact behavior of the fabric.

\section{REFERENCES}

1) F. P. Bowden and D. Tabor; Proc. Roy. Soc., A169, 391 (1939)

2) R. Holm; "Electric Contact", Almquist and Wiksells, Uppsala (1946)

3) N. Soda; "The Friction", Iwanami-shinsho, 132 (1971)

4) A. Suzuki; J. Soc. Fiber Sci. Tech. Jpn., 38, T-290 (1982)

5) Fuji Photo Film Co. Ltd.; Catalogue of Fujifilm Prescale

6) T. Fukui and T. Sekiguchi; J. Soc. Fiber Sci. Tech. Jpn., 36, P-313 (1980)

7) A. H. Oppal and S. D. Probert; Wear, 22, 163 (1972)

8) Y. Shimizu, T. Yoshimura, T. Misaizu, and A. Konda; The Summary of Autumn Symposium of Soc. Fiber Sci. Tech. Jpn., 15 (1974)

9) Herz, H.; Z. Reine u. Angew. Math., 92, 156 (1881)

10) Bowden, F. P. and Tabor, D.; "The Friction and Lubrication of Solids", Oxford Univ. Press, London (1950)

\section{画像処理による布一平面接触挙動の解析}

$\begin{array}{ll}\text { 信州大学䋊維学部 } & \text { 清 水 義 雄 } \\ \text { 宇都宮大学教育学部 } & \text { 清 水裕子 } \\ \text { 信州大学緎維学部 } & \text { 近田淳雄 }\end{array}$

編織布や紙の上うな瀻維の集合した物体の接衤挙動を 解明するために，繊維集合体一固体表面間の接触状態を 各種生力下で測定する装置を開発した。この装置はサン プルに正力を印加する部分，接螌状態を検出する部分お よび検出されたデータ在解析する部分からなっている。 本装置在用いてポリエステルタフタの接触状態の正力 依存性を測定し解析した結果，このようふ細デニールの クリンプの强い経系と太デニールの比較的真直ぐな緯系
からなる布では，各種王力下の接触挙動は大きくわけて 次の4つの領域加らなるととがわかった。すなわ方，氐 力の增大とともに(1)弾性接触域，(2)経糸中のフィラメン トの扁平変形領域，(3)緯糸中のフィラメントの接触領域, (4)接触フィラメントの相互干涉領域の 4 領域老示す。

このように本測定荠置は，布の上うな複雑な接触表面 をむつものの接触面の解析に非常に有用であることが確 められた。 